Ambiente \& Água - An Interdisciplinary Journal of Applied Science
ISSN 1980-993X - doi:10.4136/1980-993X
www.ambi-agua.net
E-mail: ambi.agua@gmail.com

\title{
Benefits and legacy of the water crisis in Brazil
}

\author{
doi:10.4136/ambi-agua.1629 \\ Marcelo dos Santos Targa; Getulio Teixeira Batista \\ Universidade de Taubaté, Taubaté, SP, Brasil \\ Programa de Pós-Graduação em Ciências Ambientais \\ E-mail: targa.marcelo@gmail.com,gtbatista@gmail.com
}

\begin{abstract}
In this editorial, we reflect on the benefits and legacy of the water crisis in Brazil between 2013 and 2014, which affected the water supply in many regions and especially in the southeast region, with emphasis on the conflict between the states of São Paulo and Rio de Janeiro over the right to use the water of the Paraíba do Sul River Basin. We analyze the current state of water resource management, the integrated use of water and energy and possible solutions to expand the availability of fresh water.
\end{abstract}

Keywords: environmental science, management, scarcity, water resources.

\section{Benefícios e legados da crise da água no Brasil}

\section{RESUMO}

No presente editorial procurou-se refletir sobre os benefícios e legados da crise hídrica no Brasil entre 2013 e 2014 que afetou o abastecimento de água em várias regiões e em especial na região Sudeste com ênfase no conflito pelo direito de uso da água da bacia do Rio Paraíba do Sul entre os estados de São Paulo e Rio de Janeiro. Procurou-se fazer nesse sentido uma análise do estágio atual da gestão de recursos hídricos, do uso integrado da água e da energia e as possíveis soluções para ampliação da disponibilidade de água para abastecimento.

Palavras-chave: ciências ambientais, escassez, gestão, recursos hídricos.

\section{DISCUSSION}

Of all water on Earth, $97.3 \%$ is salty and only $2.7 \%$ is fresh. Of the fresh water, $1.95 \%$ is in the form of polar cap ice, $0.60 \%$ is underground water and only $0.15 \%$ is in rivers and lakes. Brazil has about $18 \%$ of the total freshwater on the planet, with water availability of 48 million liters per inhabitant-year of the most readily available forms as in rivers and lakes (UNESCO, 2012), but $80 \%$ of the water is concentrated in the Pantanal and Amazon regions that include only $20 \%$ of the population. On the other hand, the remaining $20 \%$ of water is available in the Southeast, South and Northeast regions, which concentrate $78 \%$ of the population (IBGE, 2011). Only $28 \%$ of 100 Brazil's largest cities have satisfactory water availability (ABES, 2013).

In terms of governance, public policies to promote industry, agriculture and trade benefit the population in terms of accessibility to goods and services. In Brazil, these policies have been directed to support specific economic sectors, such as the automotive and electronics 
industries, which promote the consumption of water, energy and food and increase pressure on natural resources.

The census of 2010 showed that $84 \%$ of Brazil's population lives in urban areas (IBGE, 2011 ) and faces pollution problems caused by domestic sewage, since only $56 \%$ of urban areas have a sewage collection network.

Long-term planning of water management and power generation is necessary in order to ensure the availability of energy and water for human consumption, animal husbandry, irrigated agriculture and industry. Although improvements have occurred in water, sewerage, energy and food production in the last 20 years, they have occurred at the expense of opening new areas with the slashing and burning of forests and soil has been rendered impermeable, decreasing water infiltration and causing rapid runoff, soil erosion and depletion, with the consequent sedimentation of rivers and degradation of underground water supplies.

Brazil, with one of the largest global reserves of water, began to have unexpected water shortages between 2012 and 2013 in various regions. This would normally be expected only in the semiarid region in the Northeast. The incidence of drought events in Brazil has been so severe that 1,485 municipalities, $27 \%$ of all municipalities in the country, have declared a state of emergency due to the occurrence of drought in 2013 (ANA, 2015a).

The semiarid region of Brazil, comprising nearly one fifth of Brazil's area $\left(970,000 \mathrm{~km}^{2}\right)$, covers eight states (Maranhão, Piauí, Ceará, Rio Grande do Norte, Paraíba, Pernambuco, Alagoas, Sergipe and Bahia) and the northeast of Minas Gerais state, and it includes $12 \%$ of the country's population. This region was called "Drought Polygon" in 1936 and in 2013 and 2014 it again faced severe lack of rain. The proposed solution of drilling wells has been ineffective because the wells' flows are low and the water has high salt content. The use of tanks that store water collected from the roofs of houses in a normal rainy season situation has made it possible for a household in the field to accumulate 7-15 cubic meters of water, enough to ensure 50 liters per resident per day for up to 300 days a year (Cirilo et al., 2010). The construction of underground dams on local properties has been important in increasing the aquifers' supply in order to compensate for the low vegetative cover and fast runoff. On the other hand, water has been transported over long distances, as seen by the ongoing construction of integrated channels in the São Francisco transposition system; however this action, when completed, may help to relieve densely populated places such as cities and places with high concentrations of irrigated fields, but it will not relieve isolated rural properties.

In the semi-arid northeast, $97 \%$ of cities issued at least one emergency decree due to drought in 2013. The highest concentration of emergency decrees (90\%) occurred in the states of Ceará, Rio Grande do Norte, Piauí, and Paraíba. The catchment area of the Parnaíba River had the highest percentage of municipalities that have decreed a state of emergency by reason of drought in 2013, with $91 \%$ of the municipalities issuing decrees, followed by the Eastern Northeast Atlantic and San Francisco watersheds, with 83\% and 61\%, respectively (ANA, 2015a).

Water scarcity has become a reality in several Brazilian states. There was great notoriety in the media regarding the lack of rain in the Southeast between 2013 and 2014, when $43 \%$ of the population of the states of São Paulo, Rio de Janeiro, Minas Gerais and Espírito Santo had shortages of water supply, especially in urban areas. This drought, considered the worst in 80 years, severely affected the lives of approximately 20 million inhabitants of the Metropolitan Region of São Paulo (MRSP).

Organized water management has come only lately to Brazil, having begun in São Paulo in 1991. A national water policy was subsequently established by Federal Law 9433/1997, following the water resources policy model of São Paulo (Law 7663/1991). Its precepts include adopting the river basin as the planning and management unit, based on decentralized, 
participatory and integrated management, with the recognition that water is a public resource of economic value and that its use, in addition to being charged for, shall be shared by all users, considering the priorities of regional development and environmental protection.

The pioneer management system of water resources of the State of São Paulo in Brazil is based on three interdependent levels: the State Water Resources Plan, drawn from the major river basin plans and updated every four years; the State Fund for Water Resources, known as FEHIDRO, established with funding from various sources, including water use fees; and finally, the consultative and deliberative boards, made up of equal numbers of representatives of state, cities and civil society that are members of the State Water Resources Council and the Watershed Committees (CBHs).

The State of São Paulo was divided into 22 Water Resource Management Units (UGRHI) and the Basin of the Paraíba do Sul River called UGRHI 2.

The basin of the Paraíba do Sul River has an area of approximately $62,074 \mathrm{~km}^{2}$, covers 184 municipalities, 88 in Minas Gerais, 57 in Rio de Janeiro and 39 in São Paulo. This Committee was a pioneer on the national scene in 2003, when it established a water usage fee and determined that the resulting revenue be used in restoration projects for the basin itself. A permit is required and a fee is charged for uptake, consumption and effluent discharge of any water volume greater than $1.0 \mathrm{Ls}^{-1}$. This fee was established after extensive discussions between the government and the various sectors of users and civil organizations represented in the Committee for Integration of the Paraíba do Sul River Basin (CEIVAP), in order to improve the quantity and quality of water in the basin (ANA, 2015b).

The Paraíba do Sul Basin, of relevance in the national outlook, is located between the major industrial and population centers of the country and the management of its water resources involves multiple and often competing interests, especially regarding the transposition of $160 \mathrm{~m}^{3} \mathrm{~s}^{-1}$ to the Guandu River Basin for power generation and other uses. In the Guandu River, the water is used to dilute effluents, to impede a saline ocean fringe $\left(30 \mathrm{~m}^{3} \mathrm{~s}^{-1}\right)$, to support industry and to supply about nine million inhabitants in the metropolitan area of Rio de Janeiro (RMRJ) (INEA, 2014).

The notoriety of the Paraíba do Sul Basin became even more evident when, in March 2014, the government of the State of São Paulo announced that it would strengthen the supply of Cantareira System, the main supply system in the MRSP, by interconnecting with the Paraíba do Sul System. This interconnection would be made by pumping a maximum of $5 \mathrm{~m}^{3} \mathrm{~s}^{-1}$ in a two-way mode in order to supply the two systems as needed.

The Cantareira System consists of the Jaguari, Jacareí, Cachoeira, Atibainha, Paiva Castro and Águas Claras reservoirs; of these, Jaguari and Cachoeira are under federal control, while the others are controlled by the state. The first four together function as a "single container" or "equivalent system" with a total of 1,459 million cubic meters, of which 973 million cubic meters (67\% of total volume) are within the normal operating range for consumption and can be removed by gravity. These reservoirs are filled by the tributaries of the Rio Piracicaba. In this equivalent system, the Jaguari and Jacarei reservoirs form a single reservoir. The tunnels and channels of the Cantareira System divert water from some rivers in the Piracicaba River Basin to the Rio Juqueri, performing a transposition into the basin of the Upper Tietê. The waters of the Rio Juqueri are then captured in the Paiva Castro reservoir. From there, the water is pumped to the Águas Claras reservoir, where it is treated by the Água Guaraú Water Treatment Plant to supply about $45 \%$ of the São Paulo metropolitan region (ANA, 2015).

The lack of rain in the Cantareira system caused one of the most important and emblematic conflicts over water use. On one hand is São Paulo, with the need to supply water for human consumption (priority 1 - highest); on the other hand is Rio de Janeiro with a water 
use permit for power generation (priority 2). After power generation, this water is used for the RMRJ supply from the Rio Guandu, for which it has no permit.

Although the National Water Agency (ANA) has been created to regulate multiple uses of water, this water shortage was critical in both technical and political terms because it preceded the presidential and state elections of 2014. Thus, in early November 2014 the Supreme Court (STF) was needed to mediate a solution that took into account the interests of the three states (SP, RJ, and MG). A solution to the conflict was reached in late November, when the Supreme Court concluded an agreement between the three states the government of São Paulo was authorized to initiate procedures for the interconnection of the Cantareira system with the Paraíba do Sul Basin waters. The definition of a new operational rule for the Paraíba do Sul System in early 2015 was a major achievement. Objective definitions of water use management in times of drought and rain minimized the conflict, with the sequence of drawdown from downstream to upstream of the basin, thus expanding storage in the Paraibuna and Jaguari reservoirs in the state of São Paulo.

One technical aspect that also must be considered, and not least in terms of shared use in the Paraíba do Sul Basin, is the fact that the LIGHT company, which generates electric power in the state of Rio de Janeiro, does not pay for the use of water on the grounds that it already transfers compensation funds for the flood areas according to the terms of Federal Law $\mathrm{n}^{\mathbf{o}}$ 7.990/1989. However, although the legislation provides that hydropower generation is not considered a consumptive use, it is only possible because of the derivation of water by pumping from the Paraíba do Sul River.

The residential sector consumes a large portion of the urban water supply and has great potential for improving conservation. In the MRSP during the water crisis, there were all sorts of individual actions, such as the collection of rain and bath water, hand washing, reuse of previously discarded water from clothing and dishwashing machines, for use in toilet flushing, washing sidewalks and floors, and the irrigation of landscaping, gardens and house plants. Subsequently, the Company of São Paulo State Water Supply (SABESP) has awarded a $30 \%$ bonus to users that reduce their monthly consumption by $20 \%$, but has also imposed a surcharge of 40 to $100 \%$ on users that exceeded average water consumption by $20 \%$ or more (SABESP, 2015).

There must be a government program to stimulate companies to exchange domestic hydraulic systems, including the use of toilets with low-flush, double flow, taps with selfclosing drives and nozzle aerators to reduce water demand in the residential sector based on technology already available in Brazil. Another important point concerns the electrical equipment using water for showers, clothing and dishwashing machines, because they use water twice, i.e., first when they are used in the residence and secondly when the water is used to generate energy, as hydropower is the largest source of electricity in the country (over $70 \%$ ).

One issue that raised deep concern in this water crisis is the high rate of water loss that occurs primarily during distribution by the Water Supply Systems (WSS) in Brazil. While the national average has been reduced from $45.6 \%$ in 2004 to $37 \%$ in 2013 , the values in some states are still very high, reaching regional averages as high as $50.8 \%$ in the North; $45.0 \%$ in the Northeast; $35.1 \%$ in the South; and $33.4 \%$ in the Southeast. However, the target goal for 2030 is to reduce these losses in the WSS to $31 \%$ (Brasil, 2014), a figure that can be considered quite modest, especially for those regions experiencing human supply crises due to water scarcity. There are opportunities for major cost reductions in electricity and water through the reduction of water loss in the distribution networks. This reduction will reduce costs by reducing the energy consumption, chemicals for water treatment, etc., and existing facilities could increase the supply of water, without expanding the production system (Tsutiya, 2001). 
At the international level, there is the example of the New York City supply system, in which more than 90 kilometers of pipes are changed each year after leaks are detected by sonar. Combined with other measures, such as Payment for Environmental Services (PES) to optimize treatment, they were able to reduce the costs by one-third compared with 25 years ago, even though the population has increased by 1 million.

Society's way of life in relation to natural resources is often discussed in various aspects, especially when facing frightening facts such as global climate change or, in a smaller time scale, the water crisis, realities to which both people and governments must adapt (UNDP 2006), especially in developing countries, where resources for investment are always limited. Priority should be placed on water conservation measures associated with a good management plan (Vairavamoorthy and Mansoor, 2006). Research and international experience have demonstrated the efficiency of PES initiatives and the need to implement them. In Brazil, both the public and private sectors of water managers have shown a gain in awareness of PES initiatives. The restoration of the Atlantic Forest, fostered by PSAs initiatives to create ecological corridors, etc., can improve water infiltration and help to recharge aquifers. With a prognosis of low precipitation in the country in 2015 and the fact that various basins of the Southeast experienced only about $50 \%$ of the predicted rainfall for the period from January to March 2015, the situation will be aggravated in the near future.

\section{FINAL REMARKS}

A crisis promotes reflection. The water crisis that Brazil has experienced since 2013, and which is expected to be exacerbated in the summer of 2015, has the benefit of inducing a comprehensive and conscious awareness on the part of the vast majority of the population that water is a finite resource which must be preserved, and that its management involves all sectors of society. The recent water shortages brought awareness to the country's entire population due to the catastrophic dimensions reported in the daily news. We must now determine which steps should be taken at the governmental level (structural) and at the individual level for the expansion and maintenance of water availability. Long-term planning is essential for its management and sustainability. Furthermore, it became apparent to society that public planners must recognize that the growth limit has been reached in many large Brazilian cities. Society asks to what extent it is correct to import resources from another region to accommodate growth in an area that no longer has those resources simply to keep that area growing.

We must think broadly; after all, water resources transcend boundaries and go beyond the limits of basins and regions. Thus, it is essential to control deforestation in the Amazon, since it is known that the Amazon forest plays an important role in rainfall in the Midwest and Southeast regions of Brazil. Brazil has been building dams in areas with high biological and cultural biodiversity, such as the Amazon, against the global trend in which the dismantling of dams has been a reality for recovering riparian ecosystems and aquatic fauna (Grable, 2014).

It is paradoxical to have simultaneous crises of water scarcity and excess as in the case of the metropolitan region of São Paulo. The crisis in Brazil reflects what occurs worldwide as summarized in the World Water Vision Report of the World Water Council (http://www.worldwatercouncil.org/library/archives/water-crisis/): "There is a water crisis today. But the crisis is not about having too little water to satisfy our needs. It is a crisis of managing water so badly that billions of people - and the environment - suffer badly". 


\section{REFERENCES}

ASSOCIAÇÃO BRASILEIRA DE ENGENHARIA SANITÁRIA E AMBIENTAL - ABES. Perdas em sistemas de abastecimento de água: diagnóstico, potencial de ganhos com sua redução e propostas de medidas para o efetivo combate. São Paulo, 2013. 45p.

AGÊNCIA NACIONAL DE ÁGUAS ANA (Brasil). Conjuntura dos recursos hídricos 2014. Brasília, 2015a. 107p.

AGÊNCIA NACIONAL DE ÁGUAS ANA (Brasil). Conjuntura dos recursos hídricos 2014: encarte especial sobre a crise hídrica. Brasília, 2015b. 30p

BRASIL. Ministério das Cidades. Plano Nacional de Saneamento Básico PLANSAB. Brasília, DF, 2014. 220p. Available in: 〈http://www.cidades.gov.br>. Access in: March 20, 2015.

CIRILO, J. A.; MONTENEGRO, S. M. G. L.; CAMPOS, J. N. B. A questão da água no semiárido brasileiro. In: BICUDO, C. E. DE M.; TUNDISI, J. G.; SCHEUENSTUHL, M. C. B. (Org.). Águas do Brasil: análises estratégicas. 1. ed. São Paulo: Academia Brasileira de Ciências, 2010. v. 1, p. 81-91.

COMPANHIA DE SANEAMENTO BÁSICO DO ESTADO DE SÃO PAULO - SABESP. A seca persiste, continue economizando. São Paulo, 2015. 2p. Available in: <http://site.sabesp.com.br>. Access in: March 20, 2015.

GRABLE, J. After the flood. Earth Island Journal, Winter 2014. Available in: <http://www.earthisland.org/journal/index.php/eij/article/after_the_flood>, 2014. Access in: March 22, 2015.

INSTITUTO BRASILEIRO DE GEOGRAFIA E ESTATÍSTICA IBGE. Censo demográfico 2010: características da população e dos domicílios. Rio de Janeiro, 2011. Available in: <http://www.ibge.gov.br/home/estatistica/populacao/censo2010>. Access in: March 22, 2015 .

INSTITUTO ESTADUAL DO MEIO AMBIENTE INEA (Rio de Janeiro). Proposta paulista de transposição do rio Paraíba do Sul e segurança hídrica do estado do Rio de Janeiro. Rio de Janeiro, March, 2014. 20p.

TSUTIYA, M. T. Redução do custo de energia elétrica em sistemas de abastecimento de água. 1. ed. São Paulo: ABES, 2001.

UNITED NATIONS DEVELOPMENT PROGRAMME UNDP. Beyond scarcity: power, poverty and the global water crisis. New York, 2006. 421p. (Human Development Report 2006). Available in: <http://www.undp.org/content/undp/en/home/librarypage/ hdr/human-development-report-2006.html>. Access in: March 23, 2015.

UNITED NATIONS EDUCATION, SCIENTIFIC AND CULTURAL ORGANIZATION UNESCO. Managing Water under Uncertainty and Risk. UNESCO, Parte 2. wwdr4, 2012. p. 230 - 370. Available in: <http://www.unesco.org>. Access in: March 22, 2015.

VAIRAVAMOORTHY, K.; MANSOOR, M. A. M. Demand management in developing countries. In: BUTLER, D.; ALI MEMON, F. (Ed.). Water demand management. London: IWA Publishing, 2006. 361 p. 